Salterella from the

Lower Cambrian of

Central Nevada

GEOLOGICAL SURVEY PROFESSIONAL PAPER 643-H 


\section{Salterella from the}

Lower Cambrian of

Central Nevada

By ELLIS L. YOCHELSON, J. W. PIERCE, and MICHAEL E. TAYLOR

\section{CONTRIBUTIONS TO PALEONTOLOGY}

GEOLOGICAL SURVEY PROFESIONAL PAPER 643-H

Description and illustration

of an unusual fossil having

laminated inner deposits

containing heavy minerals

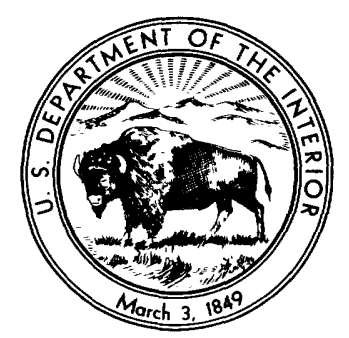

UNITED STATES GOVERNMENT PRINTING OFFICE, WASHINGTON : 1970 
UNITED STATES DEPARTMENT OF THE INTERIOR

WALTER J. HICKEL, Secretary

GEOLOGICAL SURVEY

William T. Pecora, Director

For sale by the Superintendent of Documents, U.S. Government Printing Office Washington, D.C. 20402 - Price 55 cents (paper cover) 


\section{CONTENTS}

$\begin{array}{rlr}\text { Page } & & \text { Page } \\ \text { H1 } & \text { Composition of Toquima Range thin sections_. } \\ 1 & \text { Variation in the Toquima Range Salterella } \\ 1 & \text { Possible origin of laminae } \\ 1 & \text { Discussion } & 4 \\ 2 & \text { References }\end{array}$

\section{L L US TR A T I O N S}

Abstract

Introduction . . .

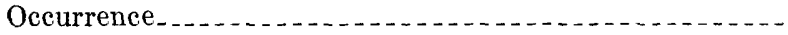

Other Great Basin occurrences and correlation ........

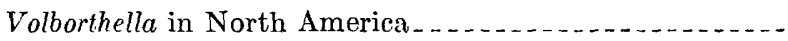

Discussion
References

Plate 1. Salterella and Volborthella.

[Plates follow references]

2-5. Salterella from Nye County, Nevada.

\section{T A B L E S}

TABLE 1. Mineralogy of discrete grains in the laminae and in the rock matrix surrounding specimens........................

2. Average size, in microns, of discrete detrital mineral grains in the laminae and in the rock matrix surrounding specimens 



\title{
CONTRIBUTIONS TO PALEONTOLOGY
}

\section{SALTERELLA FROM THE LOWER GAMBRIAN OF CENTRAL NEVADA}

\author{
By Eluis L. Yochelson, J. W. Pierce, ${ }^{1}$ and Michael E. Taylor
}

\begin{abstract}
Specimens of Salterella Billings, 1861, in a probable thrust plate in the southern part of the Toquima Range of central Nevada indicate the presence of Lower Cambrian rocks. These rocks may be correlative with part of the Harkless Formation in southwestern Nevada and adjacent California, although details of the range of salterella species remain unknown.

Many of the better preserved Toquima Range specimens have interior laminations around a central tube. The laminae are composed of discrete grains of clastic origin in a brown matrix of calcite and (or) microcrystalline quartz replacing calcite. Grains within the laminae are smaller than the average size of grains in the surrounding rock. The size difference, as well as enrichment in accessory heavy minerals, suggests a deliberate size selectivity.

Continuous variation exists between specimens in which most laminae are primarily quartz grains and those in which many of the laminae are composed of dark minerals. Specimens having laminae formed mainly of dark-colored grains resemble Volborthella Schmidt, 1888. Volborthella may be similar to Salterella except that in Volborthella the outer shell is not preserved.
\end{abstract}

\section{INTRODUCTION}

Salterella was collected by F. G. Poole of the U.S. Geological Survey in 1967 from rocks in a probable thrust plate in the Toquima Range, Nye County, Nev. In the absence of more characteristic fossils, this occurrence of Salterella is of value in confirming the presence of Lower Cambrian rocks. Furthermore, the newly discovered material provides additional data on composition of hard parts. The biological placement of the genus-a vexing problem since the original generic description by Billings in 1861-continues to be a problem and, if anything, the new specimens complicate it.

This study of Salterella would have been impossible without the specimens collected by F. G. Poole. It was aided materially by thin sections prepared by William Pinckney and by photomicrographs taken by David Massie, both of the U.S. Geological Survey. Eugene Jarosewich, U.S. National Museum, determined the

\footnotetext{
${ }^{1}$ Department of Paleobiology, U.S. National Museum, Washington,
}

presence of iron-bearing mineral grains within specimens by use of an electron probe.

\section{OCCURRENCE}

The specimens illustrated were obtained at USGS locality $6267-\mathrm{CO}$, from the west-central part of sec. 8 (unsurveyed), T. 7 N., R. 43 E., in the Willow Spring area of the southern Toquima Range, Nye County, Nev. A few other specimens were obtained at locality 6266 CO in the SW1/4 sec. 8, T. 7 N., R. 4.3 E. In addition to the specimens of Salterella described below, a few scraps of olenellid trilobites occur at locality $6267-\mathrm{CO}$, and "Hyolithes" occurs at locality 6266-CO.

Because Salterella can be easily recognized with a hand lens, it holds considerable promise as a field guide for dating and mapping. It is hoped that this raper will lead to collection of Salterella from other localities in the Great Basin.

\section{OTHER GREAT BASIN OCCURRENCES AND CORRELATION}

Salterella has been collected previously from southwestern Nevada, but the details of its occurrence are somewhat vague, and no attempt has been mac'e to describe or differentiate species in stratigraphic sequence. The genus apparently was first noted by C. D. Walcott in a collection he made in 1896 , labeled " $\mathrm{Kum}$ mit on road, Silver Peak to Fish Lake Valley." In 1899, F. B. Weeks, attached to H. W. Turner's field pr.rty, collected other specimens from a number of localities within the Silver Peak quadrangle; Turner (1909) mentioned the occurrence of Salterella only in general terms in the greenish slates and limestones of Early Cambrian age. Walcott (1908, p. 189) reported Salterella at two horizons within his Barrel Spring, $\mathrm{I}^{\top} \mathrm{ev}$, section, but in his later work on Cambrian brachionods (Walcott, 1912, p. 138), he noted only a single occurrence, probably because one of the beds may not have yielded associated brachiopods. 
Salterella was collected from the Harkless Formation (Nelson, 1962) in Nevada during 1960 by J. Wyatt Durham and E. H. McKee of the University of California, Berkeley. Their material is from the same general area in Esmeralda County, Nev., where Walcott and Weeks collected. Specimens were obtained in the Magruder Mountain quadrangle, about one-fifth mile south of the "Palmetto Wash" road along the top of a flat hill in the NW1/4 NW1/4 sec. 13, T. 6 S., R. 39 E. (Univ. of California, Berkeley, Mus. Paleontology loc. B-4035). In addition to Salterella, the trilobite Bonnia sp. is also in the Berkeley collection.

A representative specimen from the Harkless Formation is shown on plate 1 , figure 1 . Representatives of Walcott's material are illustrated on plate 1, figure 3; probably his specimens are also from the Harkless Formation. This Esmeralda County material is not well preserved, but because of its general similiarity to that collected by Poole, correlation of the southern Toquima Range Salterella-bearing beds with the Harkless is suggested.

Additional collections from both areas may eventually make possible more refined correlations within the Harkless and equivalent rock units; fossil material and relevant stratigraphic information for such study are not currently available. Only recently has it been noted that not only does Salterella have considerable stratigraphic utility as a guide to Early Cambrian age, but details of the range of species may be useful for local zonation and correlation (Yochelson and others, 1968).

Even without more detailed data, the occurrence of Salterella is significant. The genus is confined to rocks of Early Cambrian age. Salterella in the fine-grained clastic strata of central Nevada corroborates Poole's initial Lower Cambrian rock assignment (F. G. Poole, written comnun., 1967) based on lithological similarity to known Lower Cambrian strata in other parts of the southern Great Basin.

\section{VOLBORTHELLA IN NORTH AMERICA}

Lipps and Sylvester (1968) recently reported the occurrence of Volborthella Schmidt, 1888, in the lower part of the Harkless Formation in the Inyo Mountains of southern California. It had not previously been reported from North America, and these authors deserve full credit for identifying this enigmatic fossil from poorly preserved specimens.

Lipps and Sylvester (1968, p. 331) reported zircon, magnetite, pyrite, and tourmaline in their specimens. Examination of their thin sections indicates that their material is at least similar to the Nevada specimens de- scribed in "Composition of Toquima Rango thin sections"; their specimens are very incomplete when compared with the Nevada specimens. The Inyo Mountains material they studied is from a somewhat metamorphosed matrix. It may be that less resistant minerals or an organic cement holding some grains in place was destroyed during metamorphism.

Volborthella is well known in the Cambrian of Europe, especially the Baltic region (Schindewolf, 1934; Prantl, 1948). Topotypical representatives of the genus are illustrated here on plate 1, figures 2,4 , and 5 .

Yochelson and Taylor in unpublished investigations during 1966 concluded that Volborthella spesimens are, in fact, poorly preserved; some of the app rent morphological features, especially the absence of an outer shell, are the result of diagenetic alteration of the fossils. This opinion was based on compariscn of wellpreserved specimens of Salterella from Pennsylvania (Yochelson and others, 1968) with topotype specimens of Volborthella. However, before the receipt of Poole's collections, it had not been possible to document fully the similarity of Salterella-like forms to Volborthellalike organisms.

\section{COMPOSITION OF TOQUIMA RANGE THIN SECTIONS}

The Toquima Range specimens of Salterella occur in a very fine grained sandstone composed primarily of subangular to rounded quartz. Most of the quartz grains in the rock are clear, although some have what is apparently an iron stain. Most of the stained grains are near Salterella individuals, and staining is rare away from the specimens.

The quartz grains are mainly in contact with adjacent grains although there is a small amount of infilling by submicroscopic particles, presumably clay. A few thin sections have areas where clay-sized particles dominate and where the quartz grains float in an argillaceous matrix.

Calcite and microcrystalline quartz are also present. Microcrystalline quartz (chert) is generally the second most abundant mineral in the rock. Calcite is rare, except in two thin sections where it is the predominant mineral (pl. 5, figs. 1,6).

Heavy minerals are rare in the matrix in which the specimens of Salterella are found, but a variety of them are concentrated in some specimens. Three examples rich in heavy minerals are indicated in table 1 . The heavy-mineral grains in the rock matrix are coarse silt size or smaller, as noted in table 2 , and hav a smaller average size within the fossils. 
TABLE 1.-Mineralogy of discrete grains in the laminae and in the rock matrix surrounding specimens

\begin{tabular}{|c|c|c|c|c|c|c|}
\hline & \multicolumn{2}{|c|}{ Pl. 4, fig. 51} & \multicolumn{2}{|c|}{ Pl. 5, fig. 32} & \multicolumn{2}{|c|}{ Pl. 5, fig. 4} \\
\hline & Laminae & Matrix & Laminae & Matrix & Laminae & Matrix \\
\hline $\begin{array}{l}\text { Quartz } \\
\text { Chert }\end{array}$ & $\begin{array}{r}31 \\
5\end{array}$ & $\begin{array}{r}57 \\
9\end{array}$ & $\begin{array}{r}16 \\
6\end{array}$ & $\begin{array}{l}76 \\
19\end{array}$ & $\begin{array}{l}30 \\
14\end{array}$ & \\
\hline $\begin{array}{l}\text { Augite } \\
\text { Hornblende..... }\end{array}$ & & & & & & \\
\hline $\begin{array}{l}\text { Staurolite_. } \\
\text { Tourmaline... }\end{array}$ & 4 & $\begin{array}{c}2 \\
\ldots\end{array}$ & 2 & 1 & $\begin{array}{l}1 \\
3\end{array}$ & \\
\hline Hypersthene. - & 1 & & & & & \\
\hline $\begin{array}{l}\text { Epidote } \\
\text { Sphene }\end{array}$ & $\begin{array}{l}3 \\
2\end{array}$ & & & & 4 & \\
\hline $\begin{array}{l}\text { Sillimanite.............. } \\
\text { Rutile }\end{array}$ & & & & 1 & & \\
\hline (n) & 1 & & 6 & & 4 & \\
\hline marily & & & & & & \\
\hline (n) & 8 & 2 & 61 & 3 & $\begin{array}{r}37 \\
2\end{array}$ & 15 \\
\hline Coru & & & & & 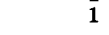 & \\
\hline Other & 8 & & 2 & & & \\
\hline $\begin{array}{l}\text { Total grains } \\
\text { counted. }\end{array}$ & 70 & 70 & 100 & 100 & 100 & 100 \\
\hline
\end{tabular}

${ }^{\imath}$ Dark-colored minerals within the matrix filling the apertural cavity include staurolite, tourmaline, hypersthene, and sphene.

2 The matrix filling the aperture contains approximately 50 percent chert and 50 percent calcite.

TABLE 2.-Average size, in microns, of discrete detrital mineral grains in the laminae and in the rock matrix surrounding specimens

\begin{tabular}{|c|c|c|c|c|c|c|c|}
\hline & $\begin{array}{l}\text { Pl. 2, } \\
\text { fig. 1, } \\
\text { and } \\
\text { PI. 3, } \\
\text { fig. 1 }\end{array}$ & $\begin{array}{l}\text { Pl. 2, } \\
\text { fig. 2, } \\
\text { and } \\
\text { Pl. 3, } \\
\text { fig. } 2\end{array}$ & $\begin{array}{l}\text { Pl. } 2 \text {, } \\
\text { fig. } 3\end{array}$ & $\begin{array}{l}\text { Pl. 2, } \\
\text { fig. } 5\end{array}$ & $\begin{array}{l}\text { Pl. } 2 \text {, } \\
\text { fig. } 4\end{array}$ & $\begin{array}{l}\text { Pl. 4, } \\
\text { fig. } 3\end{array}$ & $\begin{array}{l}\text { Pl. } 5 \\
\text { fig. } 2\end{array}$ \\
\hline 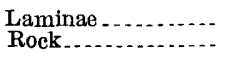 & $\begin{array}{r}58 \\
171\end{array}$ & $\begin{array}{l}53 \\
88\end{array}$ & 149 & $\begin{array}{r}61 \\
100\end{array}$ & $\begin{array}{l}49 \\
89\end{array}$ & $\begin{array}{r}66 \\
106\end{array}$ & 64 \\
\hline
\end{tabular}

The specimens of Salterella show four distinct areas (for example, pl. 3, fig. 1). The first, the shell wall, is composed of calcite or microcrystalline quartz replacing calcite. The second is the part just posterior of the aperture and is termed here the apertural cavity. This is usually filled with clastic material similar in size and composition to that of the surrounding rock. There is no evidence of lamination or sorting of the material within this apertural cavity. The third area, extending from the apertural cavity to the apex, is a central tube, which is now filled with sparry calcite.

Finally, a series of laminae, which extend from the central tube to the outer wall, is present in nearly all specimens of Salterella. There is considerable variation in the appearance of the laminae. In some instances, the laminae are composed of alternating layers of dark material and mineral grains (pl. 2, figs. 1, 2, 4, 5; pl. 3 ; pl. 4 , figs. 5,$6 ;$ pl. 5 , figs. 4,5 ). In other specimens, the laminae can be differentiated only by the color density of the material and by the inclusion of a few lighter colored detrital mineral grains within the laminae (pl. 2 , fig. 3 ; pl. 4, figs. 2,$4 ;$ pl. 5, figs. 2, 3). Between the outer shell wall and the laminae of detritus is an irregular thin layer of calcite or microcrystalline quartz, shown in most photographs, but especially prominent on the left side of plate 3 , figure 1 . Detailed microsc spic examination indicates that this apparent layer is actually formed by extension of the laminae up along the inner surface of the shell wall.

In most instances, the nongranular dark material in the photographs is either calcite or microcrystalline quartz, presumably replacing the calcite. Calcite and (or) microcrystalline quartz appears to be the cementing material holding the detrital grains in place.

In a few specimens no laminae are present (pl. 5, fig. 1) or the laminae are poorly preserved (pl. 5, fig. 6). Many of the individual lamina are broken or bent. Material filling the shell is similar to that of the surrounding rock. No indication of a central tube is present in these specimens. This absence suggests that inner lamination was lost after death, and the hollow shell was then filled by the detrital matrix.

The discrete grains within the laminae of the $S a^{\top} t e r-$ ella specimens are predominantly clear quartz. It appeared upon examination that the grain size within the laminae was smaller than that of the surrounding rock and that heavy minerals were concentrated within the laminae. To check on the concentration, point-count determinations were made on three specimens particularly rich in heavy minerals and on the surrounding rock matrix (table 1).

Quartz makes up 16 to 44 percent of the discrete grains within the laminae of all specimens courted, whereas 68 to 81 percent of the discrete grains in the rock matrix of the same thin sections are quartz. In all instances, quartz is at least 1.8 times as abundant in the rock as in the laminated part of the Salterella specimens. Chert is the second most abundant mineral in the rock matrix. The rest of the discrete grains are heavy minerals.

The longer axes of discrete grains were measuret in seven specimens in which definitive laminae were $F^{\text {res- }}$ ent and in the rock surrounding each of the specimens (table 2). In all instances, the average length of the grain axes in the laminae was less than that of the grains forming the rock. The range in size in the rock was greater than within the laminae, inasmuch as some of the grains within the rock were of the same size range as those within the laminae. No grains within the laminae were as large as the average for the rack, except where infilling might have been possible, such as near the juncture of the apertural cavity and the upper laminae.

There appears to be an apparent selectivity by the organism based on grain size, the smaller grains being preferentially enriched within the laminae. The concentration of heavy minerals within the laminae, at loast 
in the three specimens on which point counts were made, is attributed to the prevalence of heavy minerals in the smaller grain sizes because of hydraulic equivalence.

One thin section was subjected to elemental analysis for silicon, magnesium, and iron by use of an ARL microprobe. Selected fields of laminae were subjected to 20 kilovolts and 0.15 microamperes. Spots of 1-micron diameter were counted for 10 seconds.

Of the three elements determined, two opaque areas were found to contain only iron. The fact that both areas are bounded by lines meeting at right angles, suggests a possible cubic crystal habit. For these reasons, we believe that some of the opaque material, especially that not in discrete grains, is iron oxide replacing pyrite.

Clear grains show the presence only of silicon. Many of the dark grains show both silicon and iron. Microscopic examination suggests that this is microcrystalline quartz replacing calcite. None of the elements tested for would be definitive for calcite, except for calcite containing magnesium.

\section{VARIATION IN THE TOQUIMA RANGE SALTERELLA}

The Salterella specimens show considerable individual variation. The differences among specimens are so great that some features are judged to be partly secondary and inorganic in origin. Accordingly, it is appropriate to consider the more striking of these differences.

So far as can be determined, the external shape is a simple high cone closed at the apical end (pl. 3, figs. $1,2)$. The wall tapers gradually along the outer onethird of the apertural cavity but is otherwise nearly constant in thickness from the shell apex to the aperture (pl. 4, fig. 5). The apertural cavity is deep, constituting approximately one-third of the total length of the larger shells. A central tube extends from the cavity to near the apex (pl. 3, fig. 1; pl. 4, fig. 1). Except for this tube, the interior of the cone is filled with laminae composed either of discrete grains in a microcrystalline matrix or of a microcrystalline material with no discrete grains. The floor of the apertural cavity is formed by the last lamina. Great variation is seen in the appearance of the laminae, but discussion of this feature is given last.

In the best preserved specimens, the wall is composed of microcrystalline calcite that has been replaced to some extent by microcrystalline quartz. In other specimens, the wall is composed of microcrystalline quartz with only a small amount of calcite remaining as remnants. In at least one specimen, part of the outer wall has been removed from the upper part of the shell, a condition leaving a series of laminae formed of siltsized grains in a dark matrix (pl. 5, fig. 2).

The apical part of some tubes is broken. Incomplete specimens may range from those having an irregular break (pl. 5, fig. 2) through those in which the apical area is separated a short distance (pl. 5, fig. 1) to those in which there is definitely no indication of an apex (pl. 5, fig. 4). The tubes that contain silt grains in laminated arrangement apparently do not lose orientation of these grains during the breaking off of the apex (pl. 5, fig. 2). This further supports the assumption that the silt grains within the laminae were held together by some matrix.

Laminae are absent, wholly or in part, from broken and distorted shells (pl. 5, figs. 1, 4), and from at least one undistorted shell (pl. 5, fig. 6). The onl " specimens examined in which no laminae, or hint of such, are present are from limestone composed primarily of sparry calcite. The atypical nature of the matrix suggests that these specimens may have been transported farther than those in the quartz sandstone and that the matrix of the laminae disintegrated during transportation.

There are differences in the depth of the apertural cavity among specimens. Some of this variation in depth may be related to ontogenetic change. However, in a few specimens the outer rim of the aperture has been broken back (pl. 2, figs. 3, 5). In still others there is a suggestion that the laminae close to the apertural cavity are missing (pl. 5, fig. 4). Difficulty in alining a thin section precisely through the center of a specimen may account for the apparent presence or absence of a central tube, but the nonlaminated specimens show no indication of this tube.

There is also variation in the external shell shape. Many specimens are straight, but some tubes are curved in thin section (pl. 5, fig. 3). Curved speciss presumed to be Salterella have been described, $\mathrm{fc}^{\circ}$ example, S. acervulosa Resser and Howell; this curvature may be the result of tectonic activity. At least a few of the specimens in the Toquima Range collection are irregular enough to suggest that curvature may be due to distortion of the containing rock. The shells that contain mainly silt grains having no clear indicatior of internal lamination are frequently the ones that show the clearest suggestion of deformation. In at least on specimen, the apical area appears to be distorted into a slightly bulbous shape from its original pointed condition (pl. 5, fig. 6).

Laminae generally are broadly and sl allowly $V$ shaped on either side of the axial tube (pl. \&, figs. 1,2). They are closely spaced and are separaterl by a few irregularly spaced dark-colored layers. Clear angular 
silt-sized quartz grains are the principal constituent of some laminae. Quartz grains may either occupy a layer completely, following the orientation of the laminae above and below it, or they may be irregularly placed along a predominantly dark-colored lamina (pl. 2, fig. 5). In some individuals, laminae composed primarily of silt-sized quartz grains may be concentrated at the lower part of the shell (pl. 5, fig. 5) and slightly coarser grains concentrated at the upper part. In others, silt-sized grains of quartz are layered mainly in the upper part of the shell (pl. 4, fig. 5). In still other shells, very rare, fine-sand-sized grains are scattered irregularly through the silt-sized grains of the laminae (pl. 4, fig. 4).

The laminae are asymptotic to the onter wall of the shell. Generally, the matrix of the laminae appears to extend some distance up the inside of the wall, so that the thin section, in transmitted light, gives the appearance of a multilayered wall (pl. 3, fig. 2).

The angle that the laminae make with the central tube is more variable than the asymptotic curvature of the outer edges of the laminae. In most instances, the laminae meet the central tube at angles ranging from $35^{\circ}$ to $52^{\circ}$. The smaller angle is generally in the lower part of the shell. However, in two specimens, the laminae flatten out after leaving the outer wall, and in the inner part of the thin section, their approach to the central tube at nearly right angles (pl. 2, fig. $3 ;$ pl. 4, figs. 2,4 ) makes a $U$ rather than a $V$ in cross section.

\section{POSSIBLE ORIGIN OF LAMINAE}

Siliceous spicules and plates are known in some living organisms, but animal secretion of quartz and heavymineral grains is so alien that it may be safely surmised that no direct physiological effect is involved in production of the laminae. Two possible explanations exist for the presence of such detrital particles as parts of laminae within the shells. First, they were implaced during the life span of the animal. Secondly, they are the result of post-mortem replacement by nonorganic processes.

The concept of post-mortem replacement of grains of selected sizes and composition which are otherwise quite rare in the surrounding rock requires such a complex set of sedimentologic circumstances as to appear nearly impossible. We therefore conclude that the laminae are biologically implaced.

Lipps and Sylvester (1968, p. 329) concluded that Volborthella had an agglutinated test and "**** was most likely a worm-like animal * * *." In a hypothesis that some sort of life process was involved in formation of laminae, the term "agglutinization" may not be fully appropriate, for it is generally used with reference to an external shell or test.
The Toquima Range specimens demonstrate quite clearly that the grain part of the organism is an internal structure surrounded by a conical shell, not an external test or tube. Most specimens show a central hollow tube of uniform diameter. The edges of the laminae maintain a nearly constant relationship to the outer wall and a predictable variation to the central tube (pl. 2, fig. $5 ;$ pl. 3 , fig. 1 ). This uniformity suggests that the tube was filled by organic material during life, the laminae being deposited around it and inside the outer wall. The grains of each lamina appear to be in a matrix of calcium carbonate, although in some specimens it is now replaced by microcrystalline quartz.

There are at least three methods by which detrital grains could be implaced behind the soft parts of the animal to fill the earlier part of the shell. First, many different sorts of animals elongate their soft parts curing feeding. This elongation process might bave slightly attenuated the soft parts, a condition resulting in a narrow circumferential gap between the rim of the aperture and the main soft body mass. Grains limite to a small size could filter in through this gap. Once in the lower part of the apertural cavity, the grains could be redistributed by movement of the main body mass into a layer one grain thick. Secretion of cement would then hold them in place.

The second method would be similar to the first but would presuppose limited movement along the bottom. During feeding, the animal would drag the shell along the bottom. Extension of the soft parts again would provide attenuation. That part of the shell in contact with the bottom would act as a scoop, and grains ecual to or smaller than a given size would enter into the apertural cavity. Redistribution and secretion of cement would then occur.

The above two methods presuppose that no material finer than silt-sized grains occurs in the environment, inasmuch as clay-sized particles would infilter along with the silt grains. Very little material smaller than silt size occurs in the Salterella specimens examir od, although it is present but rare in the Toquima Range matrix rock. However, if Volborthella from Estonia is a similar animal, it would hardly seem likely that the clay of the surrounding rock in which Volborthella occurs (pl. 1, fig. 5) could be excluded by either of the above processes.

The third and probably the most logical explanation is purposeful selection by the organism, discrimination being based on grain size only. The processes by which the organism might select and emplace the grains is not known, although some sort of tentacular apparatus would be required to pick up a grain and move it to the edge of the aperture. 
The variation between laminae, whether primarily grains having a small amount of cement or primarily calcium carbonate having few grains, can best be explained by one of two methods or perhaps a combination of them :

1. When grains of the preferred size were plentiful in the immediate area of the organism, laminae of grains, cemented by calcite, were formed. After the supply was depleted and before replenishment by currents or before it could move into an area having a sufficient number of grains, the organism was forced to secrete calcite to maintain the proper size apertural cavity consistent with body size.

2. Alternatively, secretion of sufficient calcite to form whole laminae may have been possible for this organism only when the water was saturated. At times of undersaturation, grains were selected on the basis of size to make up for the deficiency of the mechanism.

As yet, insufficient data are available to determine which of the above mechanisms was dominant. For example, in contrast to the Toquima Range material, some Salterella from Pennsylvania occur in limestone. In that area, there may have been no detrital grains available, or the water may have been saturated enough of the time with calcium carbonate to permit the carbonate-secreting mechanism to function so as to permit formation of laminae at a satisfactory rate without the need for selection of foreign mineral grains.

\section{DISCUSSION}

The most interesting biological feature of this material is the admixture of a calcium carbonate outer shell and the quartz-rich or dark-mineral-rich inner laminae. In contrast, well-preserved specimens of Salterella of similar size and external shape from limestones in the eastern United States contain calcium carbonate in the interior and show no detrital grains of quartz or heavy-mineral grains.

The alternating areas of light and dark bands are difficult to count, but about 100 laminae occur in the larger specimens. The age and growth rate of these fossils are unknown. A life span of less than a year is at least within the order of magnitude for age of growth of recent calcium carbonate-secreting animals in the same general size range. Accordingly, each laminae could be the result of a body extension coupled with a diurnal feeding cycle.

The question of destruction versus preservation of laminae may be dependent upon time and distance of transport between death and burial. Exposure on the sea bottom would tend to cause a breakdown of the cement or matrix of the laminae by solution. Movement of the shell would hasten loss of laminae if specimens were poorly cemented.

The bulbous tip on one specimen (pl. 5, fig. 6) and the varying diameter of other tubes are similar to features characteristic of fossils assigned to the enigmatic Wyattia Taylor (1966) described from upper Precambrian rocks in eastern California (see Cloud and Nelson, 1966, for differing opinions on age assignment). Though evidence does not warrant placing Volborthella and Wyattia in synonymy with Salterella at this time, the preservation of the Toquima material dres suggest that both of these generic names should be applied with caution to specimens not from the type areas because of the possible influence of diagenetic features on the fossils.

Destruction of the outer shell wall can be by abrasion before burial or by solution of the calcite after burial. In the Estonian specimens of Volborthella cnly the outer shell is missing, and the edges of the laminae are truncated along a rather straight line (pl. 1, figs. 2, 4, and 5). This would indicate solution of the outer wall rather than abrasion, which would tend to create a rougher outline.

It is obvious from the Toquima Range specimens that some Salterella may be highly variable. Variation in laminae composition has been noted; this may be partly controlled by the environment in which the animal lived. Variation during ontogeny may be observed in the shape of the inner laminae, those in the juvenile part of the shell being more strongly inclined tran those in the upper part of the tube.

Finally, there is the problem of the limits of individual variation. Most specimens in the Toquima Range collection have $V$-shaped inner laminae. Two (pl. 4, fig. 4 ; pl. 5, fig. 2) having broadly U-shaped. inner laminae may represent another species, but this is uncertain.

The obvious distinction in shape between the laminae of the Estonian Volborthell $a$ and Nevada specimens of Salterella show that forms can be distinguished, though the level of significance to be assigned to such differences remains unknown. With the large number of variables available in Salterella, it seems advisable to delay any formal species description until additional material from other localities has been examined.

\section{REFERENCES}

Billings, Elkanah, 1861, On some new or little known species of Lower Silurian fossils from the Potsdam Group (Primordial zone), in Hitchcock, Edward, Hitcheock, Edward, Jr., Hager, A. D., and Hitchcock, C. H., Report on the geology of Vermont; descriptive, theoretical, economical, and scenographical : Claremont, N.H., v. 2, p. 942-955. [This material was reproduced in Palaeozoic Fossils, volume 1: Canada Geol. Survey, 1865, p. 1-18.] 
Cloud, P. E., Jr., and Nelson, C. A., 1966, Phanerozoic-Cryptozoic and related transitions-new eridence: Science, v. 154 no. 3750 , p. $766-770$.

Lipps, J. G., and Sylvester, A. G., 1968, The enigmatic Cambrian fossil Volborthella and its occurrence in California: Jour. Paleontology, v. 42, no. 2, p. 329-336, pl. 43.

Nelson, C. A., 1962, Lower Cambrian-Precambrian succession, White-Inyo Mountains, California: Geol. Soc. America Bull., v. 73, no. 1, p. 139-144.

Prantl, Ferdinand, 1918, On the occurrence of the genus Volborthella Schmidt in Bohemia (Nautiloidea) : Praha, Národni Mus., Sbornik, v. 4B, no. 5, Geologia et Paleontologia, no. 3, 13 p., 1 pl.

Schindewolf, O. H., 1934, Bau und systematische Stellung der Gattung Volborthella Schm.: Palaeont. Zeitschr., v. 16, no. 3-4, p. 170-197, pls. 17-19.
Taylor, M. E., 1966, Precambrian mollusc-like fossils from Inyo County, California: Science, v. 153, no. 3732, p. 19?--201.

Turner, H. IV., 1909, Contributions to the geology of the Silver Peak quadrangle, Nevada: Geol. Soc. America Bull., v. 20, p. 223-264.

Walcott, C. D., 1908, Cambrian geology and paleontologyNumber 5, Cambrian sections of the Cordilleran area: Smithsonian Misc. Colln., v. 53, p. 167-230.

1912, Cambrian Brachiopoda: U.S. Geol. Survey Mon. 51, pt. 1, 873 p. ; pt. 2, 363 p., 104 pls.

Yochelson, E. L., Taylor, M. E., and Cloos, Ernst, 196ع, The Lower Cambrian genus Salterella at Thomasville, Pennsylvania [abs.]: Geol. Soc. America, Northeastern Sec., 3d Ann. Mtg., Washington, D.C., Program, p. 64. 
PLATES 1-5 


\section{PLATE 1}

[All photomicrographs taken in plain transmitted light]

Figures 1, 3. Salterella sp.

1. Specimen from Harkless Formation; University of California, Museum of Paleontology, locality B-4035; × 25. USNM 165260.

3. Specimen from USGS locality 180 (green series). Labeled "Cambrian. Summit on road, Silver Peak to Fish Lake Valley"; $\times 10$. USNM 165262.

2, 4, 5. Volborthella tenuis Schmidt from slab labeled "Lower Cambrian (lower clay);

Karlshof, Brigitten Fluss, near Reval, Estland." The slab was collected by A. Mickwitz in 1903, and it appears identical to other material in the U.S. National Museum collected by Fr. Schmidt and presumably identified by him as this species. USNM 165261.

2. A moderately well preserved specimen; $\times 50$.

4. Several specimens including the one shown in fig. $2 ; \times 10$.

5. Two additional specimens; $\times 30$. 

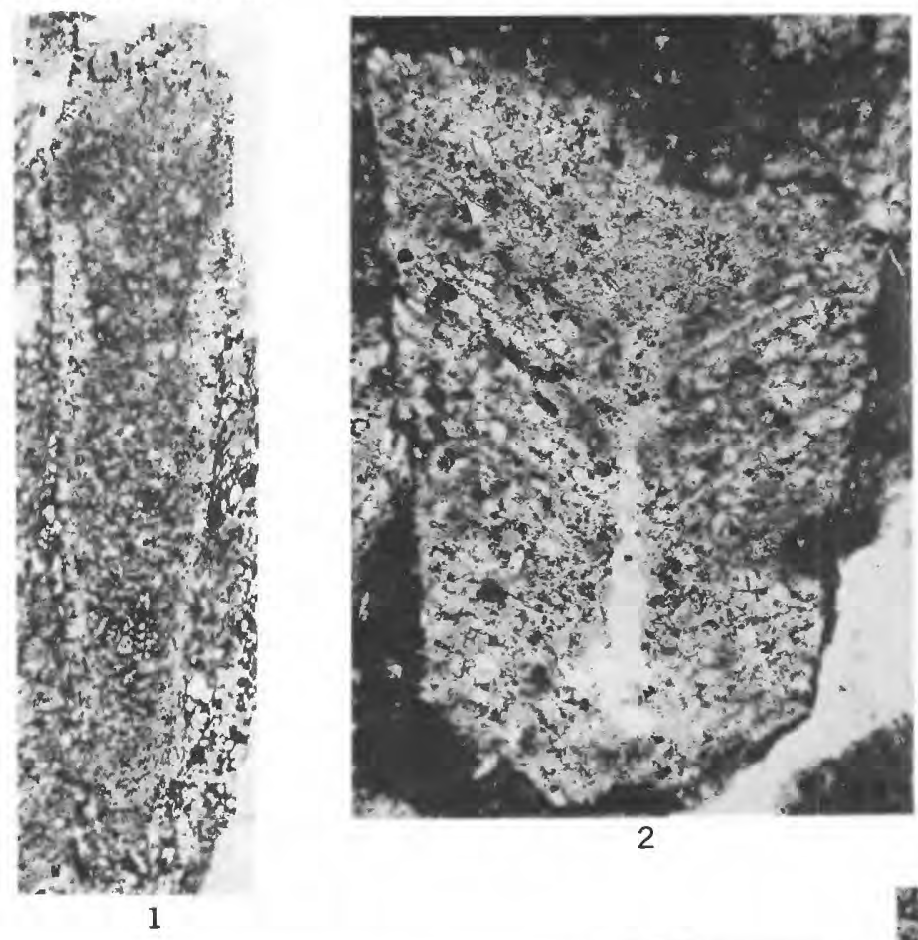

2

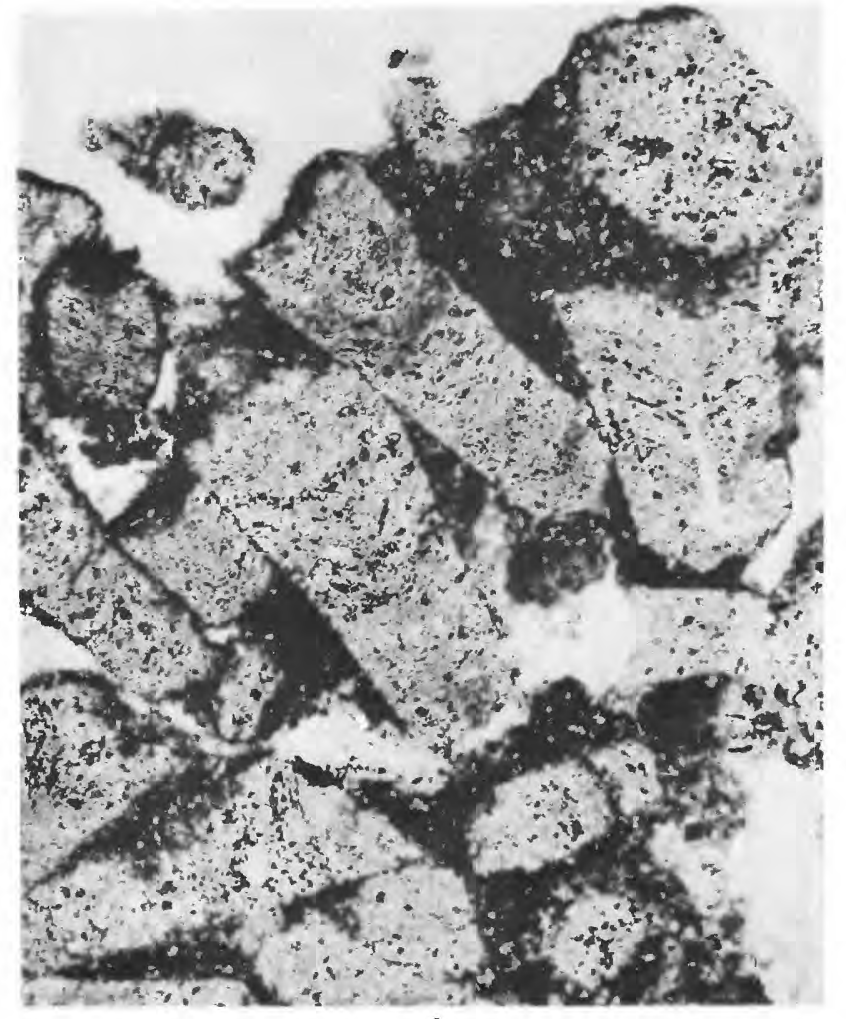

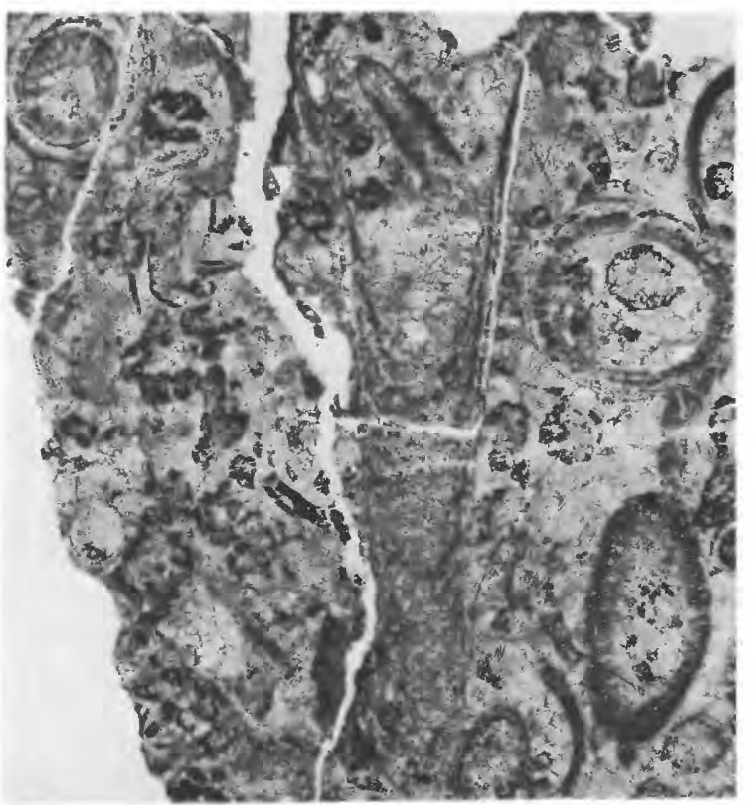

3

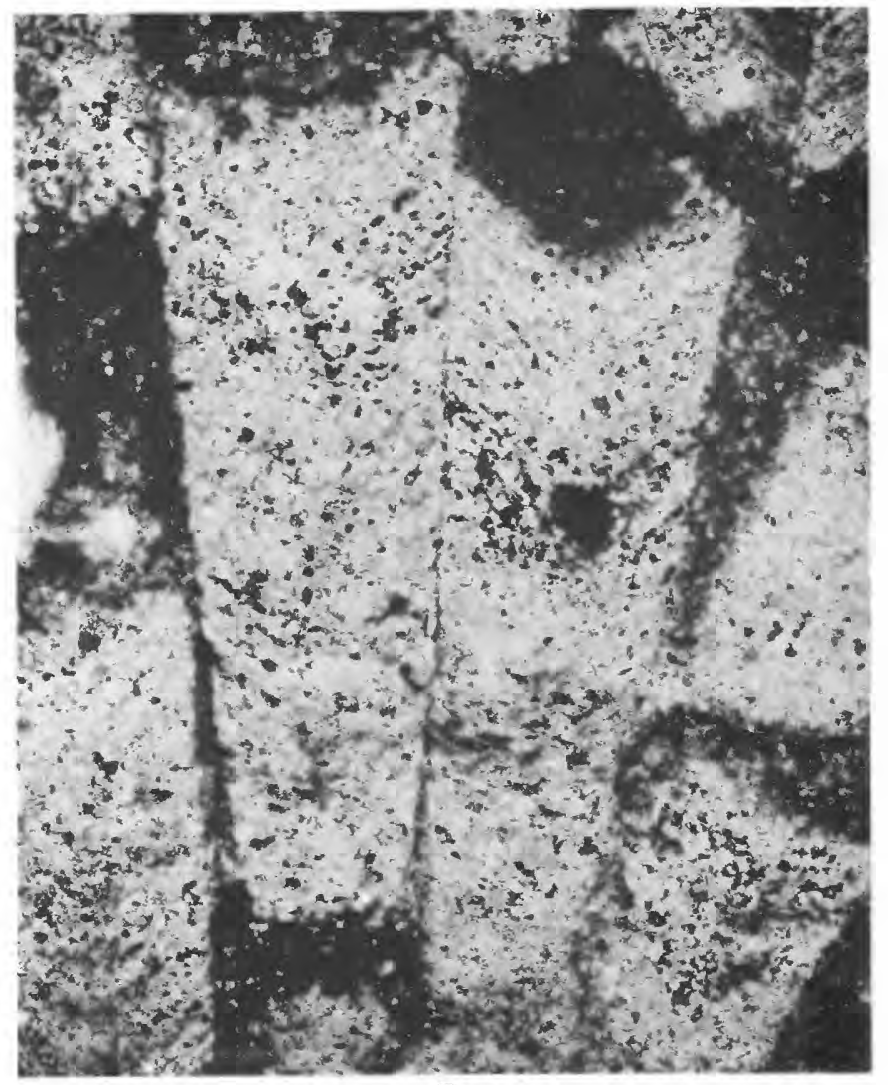

5

SALTERELLA AND VOLBORTHELLA 


\section{PLATE 2}

[All photomicrographs taken in plain transmitted light]

Figures 1-5. Salterella from USGS locality 6267-CO.

1. Specimen showing the central tube filled with calcite; laminae asymptotic to wall, meeting central tube at an angle of approximately $30^{\circ} ; \times 10$. USNM 165263.

2. Specimen showing several alternating light- and dark-colored bands; $\times 10$. USNM 165264 .

3. Specimen showing dark bands and apertural breakage; most grains in laminae not well oriented; $\times 30$. USNM 165265.

4. Small specimens-the one in the upper right showing the inner tube and the lower central specimen, one of those examined with electron probe; $\times 10$. USNM 165266 .

5. Small specimen from same thin section as fig. 2 , although not the same specimen; variable angle between laminae and central tube of between $35^{\circ}$ and $52^{\circ}$; most grains in laminae are well oriented; $\times 30$. USNM 165267 . 
GEOLOGICAL SURVEY

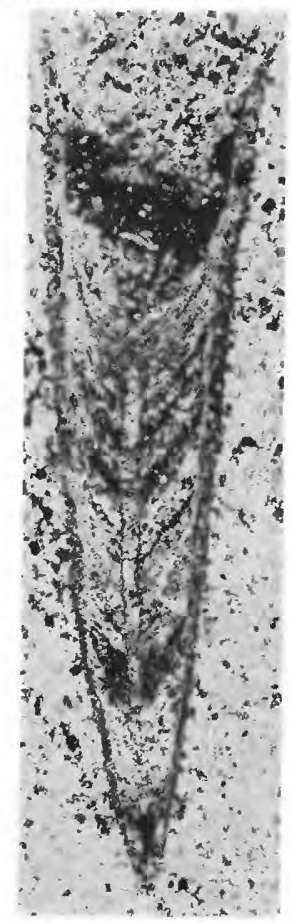

1

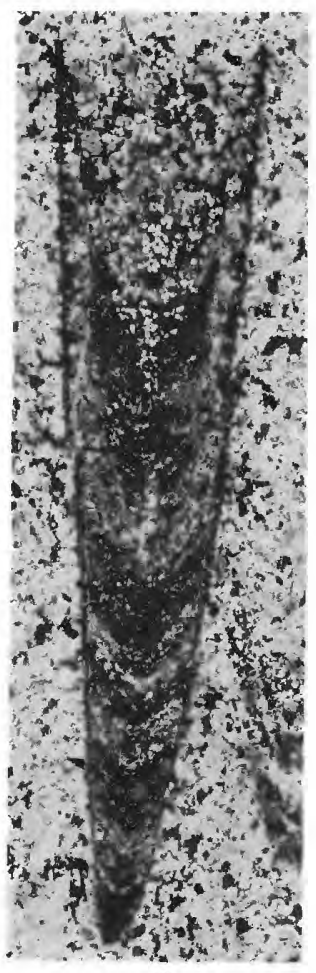

2

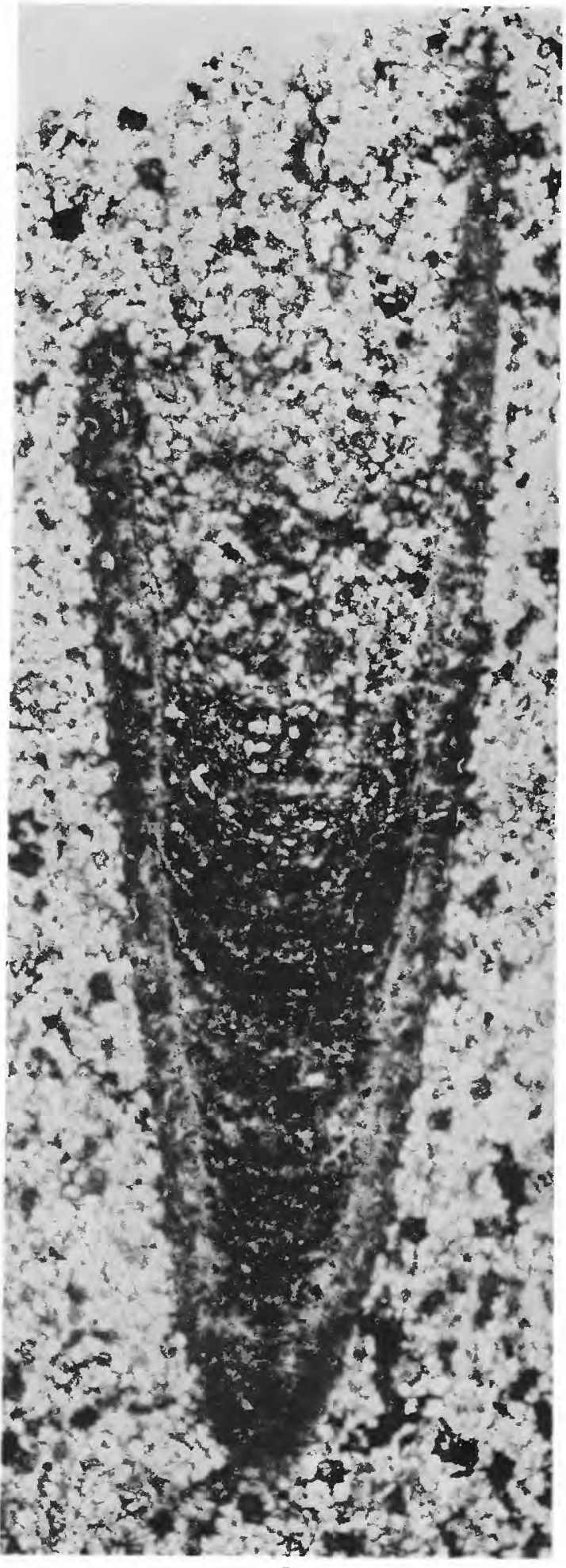

3
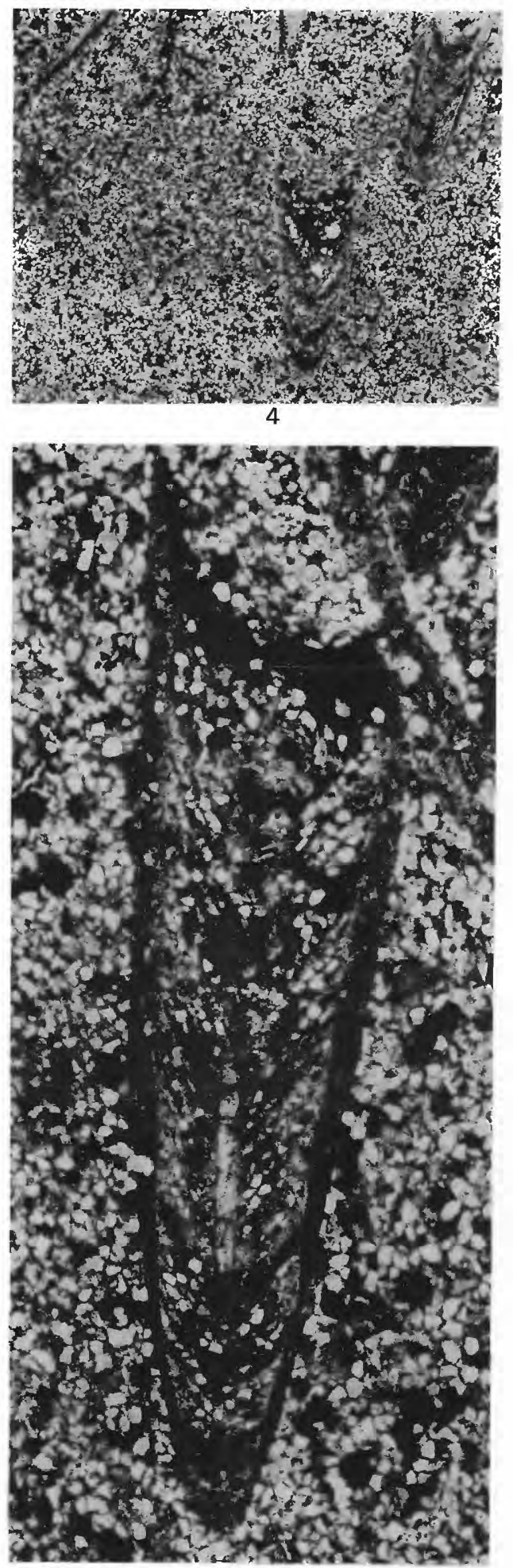

5

SALTERELLA FROM NYE COUNTY, NEVADA 


\section{PLATE 3}

[All photomicrographs taken in plain transmitted light]

Figures 1, 2. Salterella from USGS locality 6267-CO.

1. Note apparent double wall formed by asymptotic laminae (same specimen as shown on pl. 2, fig. 1); $\times 25$. USNM 165263.

2. Same specimen as shown on pl. 2 , fig. $2 ; \times 25$. USNM 165264. 

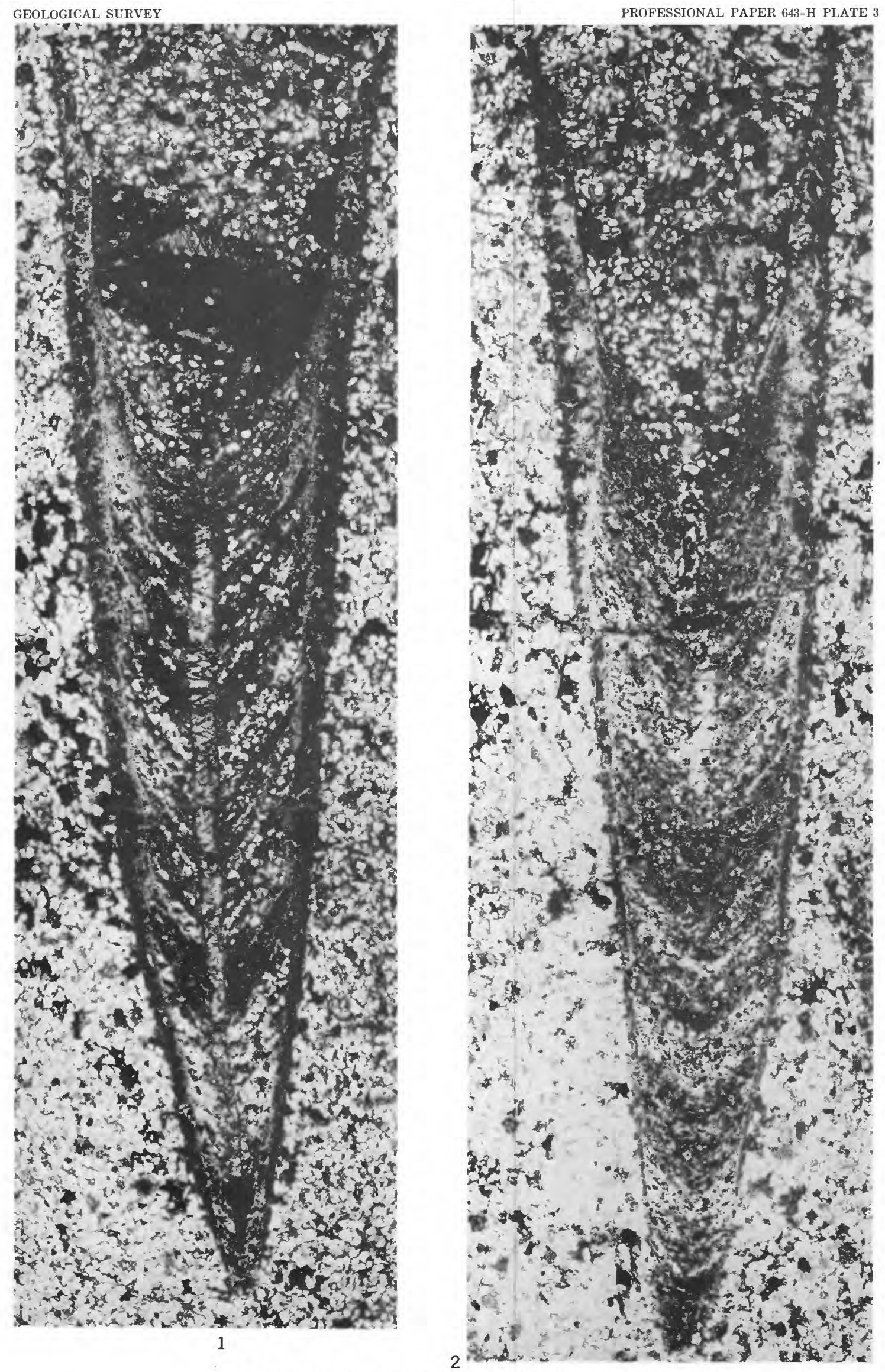

SALTERELLA FROM NYE COUNTY, NEVADA 


\section{PLATE 4}

[All photomicrographs taken in plain transmitted light]

Frgures 1-6. Salterella from USGS locality 6267-CO.

1. Oblique cross section; apparent double wall with outer part calcite and inner part calcite and microcrystalline quartz; $\times 30$. USNM 165268.

2. Cross section (same specimen as fig. 1) and longitudinal section (same specimen as fig. 4); $\times 10$. USNM 165269.

3 6. Specimen taken from same thin section as shown on pl. 2, fig. 4; most of laminae are silt-sized quartz grains in poor orientation; $\times 10$ and 20 (fig. 6 taken with crossed polarizers). USNM 165270.

4. Part of specimen shown in fig. $2 ; \times 30$. USNM 165269.

5. Well-preserved specimen showing staining of matrix in apertural cavity; note laminae extending along wall; $\times 10$. USNM 165271. 
GEOLOGICAL SURVEY
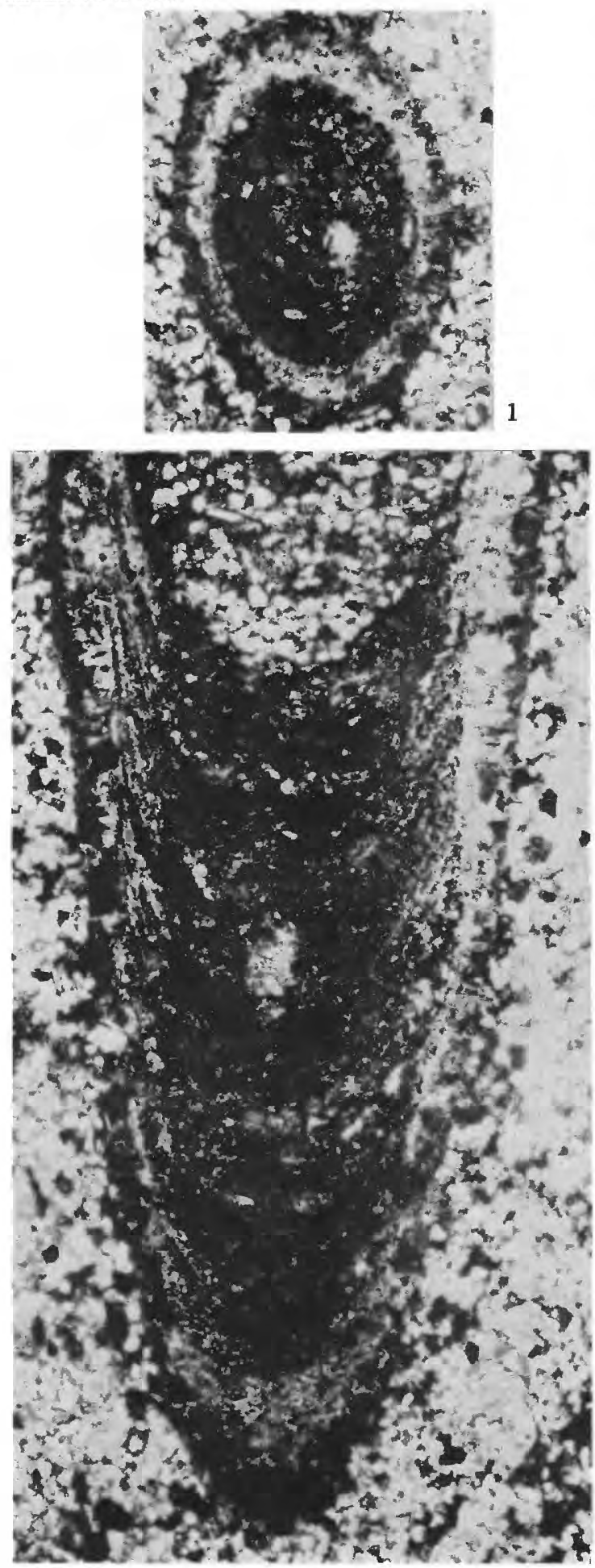

4
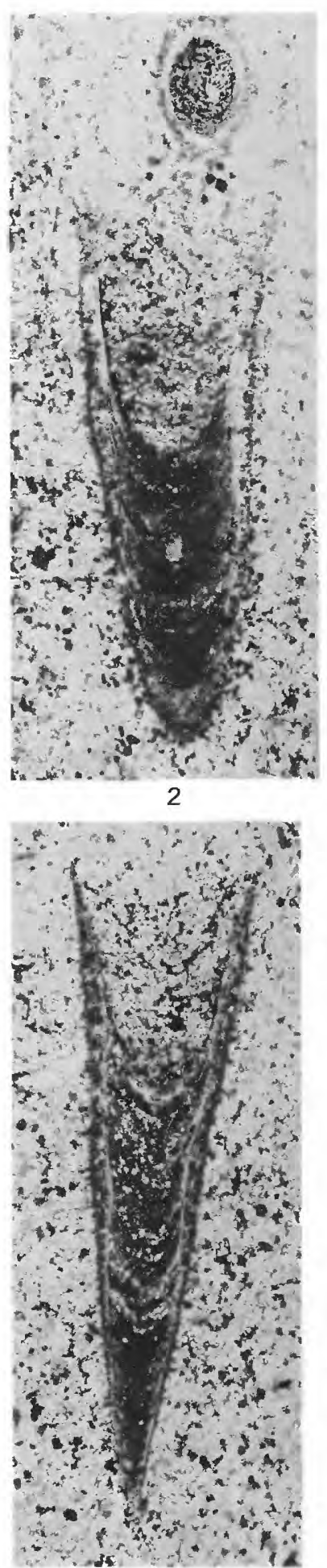

5
PROFESSIONAL PAPER 643-H PLATE 4
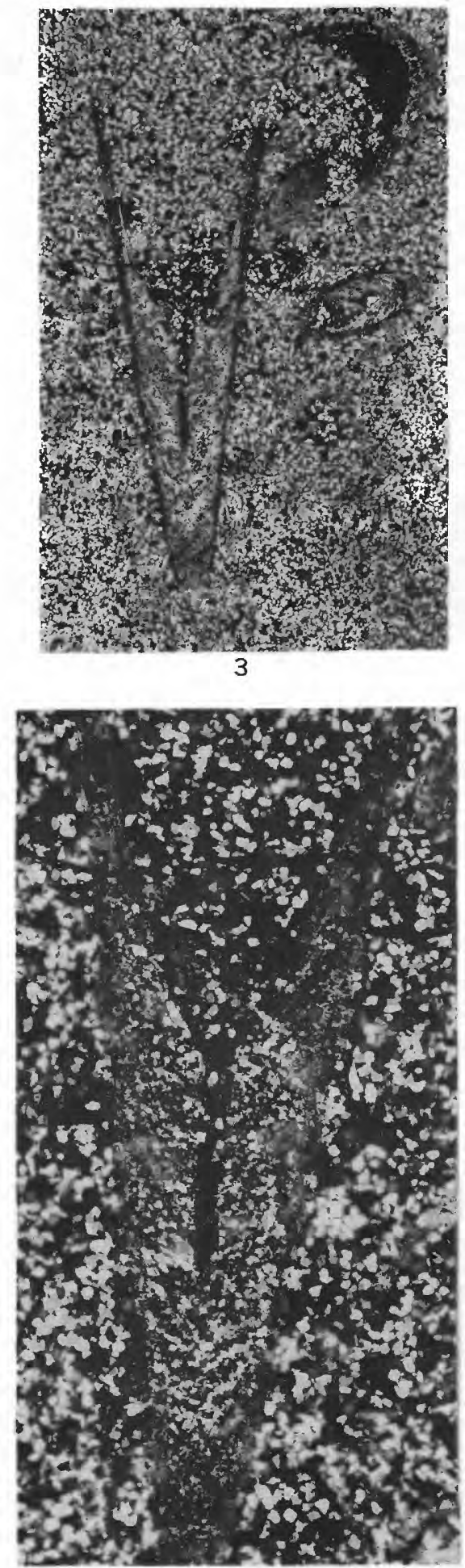

6

SALTERELLA FROM NYE COUNTY, NEVADA 
PLATE 5

[All photomicrographs taken in plain transmitted light]

FIGURES 1-6. Salterella from USGS locality 6267-CO.

1. Specimen somewhat eroded at the lower part and without evidence of laminae; rock and shell filling are primarily calcitic; $\times 10$. USNM 165272.

2. Specimen with apex broken off but without loss of inner laminae; $\times 30$. USNM 165273 .

3. Several specimens, the one to the left apparently bent as suggested by abrupt changes in the geometry of the outer wall; laminae above bend distorted and broken but complete and regular below; $\times 10$. USNM 165274.

4. Poorly preserved specimen having the apical portion separated from the remainder of the specimen; note destruction of laminae below break; $\times 30$. USNM 165275.

5. Well-preserved specimen showing a part of the central tube near the apex, from same thin section as pl. 2 , fig. $2 ; \times 10$. USNM 165276.

6. Distorted specimen showing outer wall and a mixture of inner deposits; no evidence of central tube; $\times 10$. USNM 165277 . 
GEOLOGICAL SURVEY

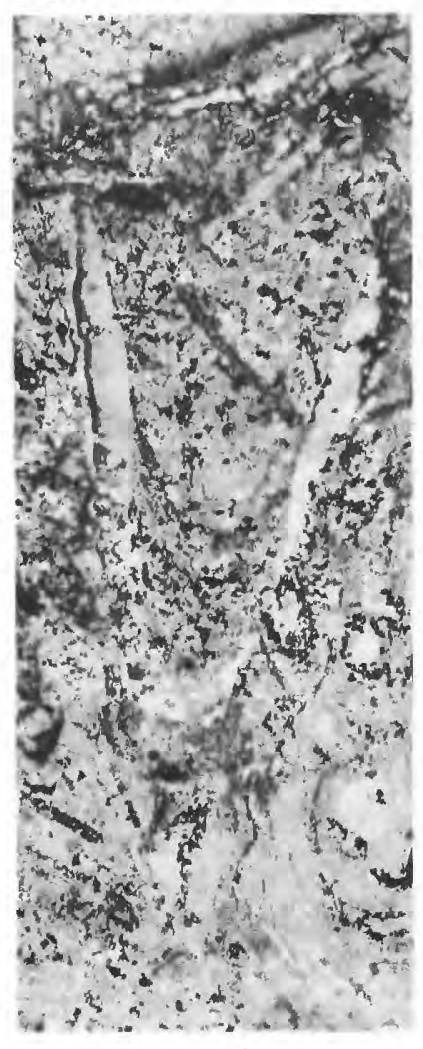

1

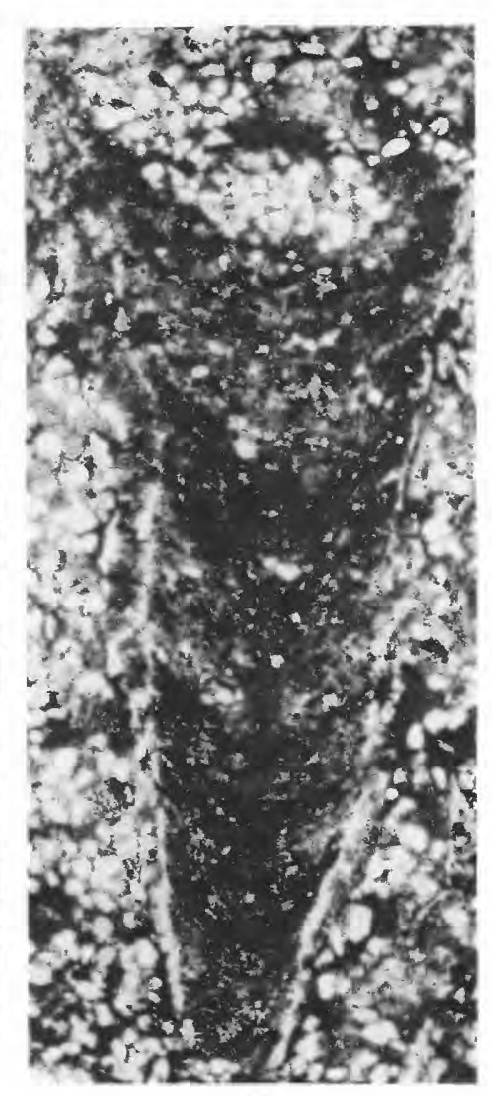

2

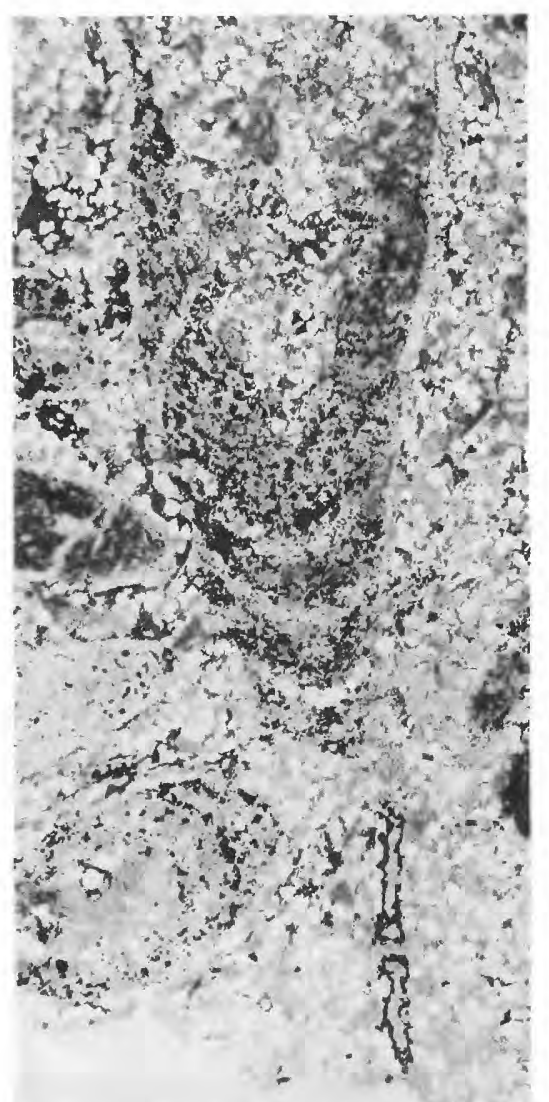

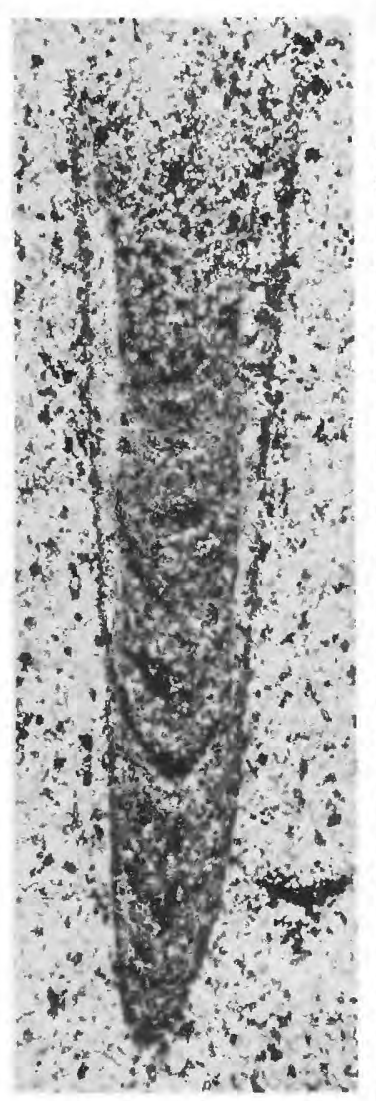

5

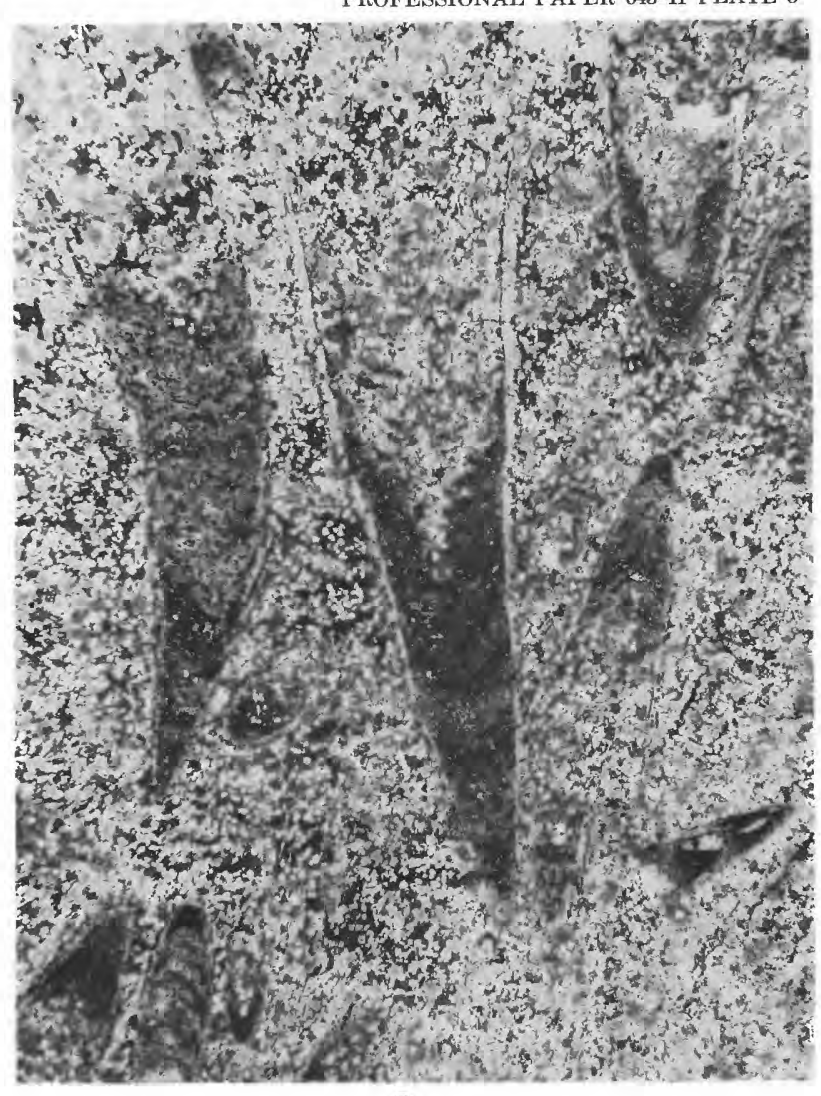

3

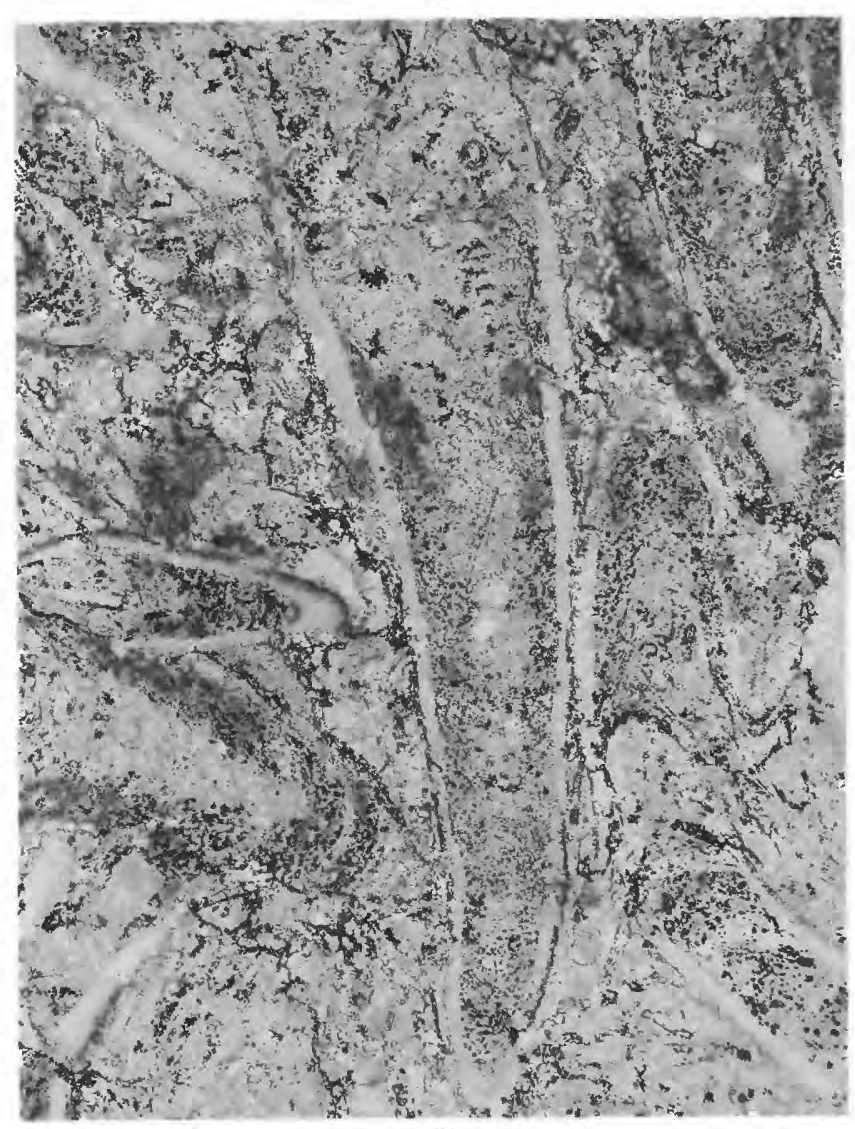

6

SALTERELLA FROM NYE COUNTY, NEVADA 
